\title{
IDENTIFIKASI STRATEGI PEMASARAN TEMPE SUCIPTO DI KOTA MANADO
}

\author{
Nurfadila \\ Juliana R. Mandei \\ Lorraine W. Th. Sondak
}

\begin{abstract}
The purpose of this study is to find out the marketing strategy of Tempe Sucipto in Manado. This study uses descriptive analysis based on Likert scale. This study is conducted from November until January 2018 located in MultiMart, Jumbo, Golden, Fiesta Ria, Transmart Carrefour, and Indomaret Plus Manado. The data used are primary data and secondary data. Primary data is obtained from interview towards 12 respondents of customers of Tempe Sucipto who have ordered Tempe Sucipto in November 2018. Secondary data is data obtained from the related literature. Results indicate that respondents are satisfied to the product Tempe Sucipto in terms of quality. Packaging, durability, and features. *lr*.
\end{abstract}

Keywords: identification, marketing strategy, Tempe Sucipto, quality, Packaging, durability, and features, Manado City

\begin{abstract}
ABSTRAK
Tujuan penelitian ini adalah untuk mengetahui strategi pemasaran Tempe Sucipto di Kota Manado. Penelitian ini menggunakan analisis deskriptif berdasarkan skala likert. Penelitian ini berlangsung selama 3 bulan yaitu dari bulan November sampai bulan Januari 2018 di MultiMart, Jumbo, Golden, Fiesta Ria, TransMart Carrefour, Indomaret Plus Manado. Data yang digunakan adalah data primer dan data sekunder. Data primer adalah data yang diperoleh dari hasil wawancara langsung kepada 12 responden pelanggan tetap Tempe Sucipto yang telah memesan Tempe Sucipto pada bulan November 2018. Data sekunder yaitu data yang diperoleh dari literature-literatur terkait. Hasil penelitian ini menunjukkan bahwa penilaian responden adalah sangat puas terhadap produk Tempe Sucipto di Kota Manado dalam aspek penilaian responden adalah sangat puas terhadap produk Tempe Sucipto di Kota Manado dalam aspek kualitas, kemasan, daya tahan dan fitur produk. *lrr*.
\end{abstract}

Kata kunci: identifikasi, strategi pemasaran, Tempe Sucipto, kualitas, kemasan, daya tahan dan fitur produk, Kota Manado

\section{PENDAHULUAN}

\section{Latar Belakang}

Sektor pertanian merupakan sektor yang paling penting baik dalam jangka panjang pembangunan ekonomi maupun untuk pemulihan ekonomi jangka pendek. Sekarang merupakan saat yang tepat untuk menggali pemikiran-pemikiran mengenai reorientasi kebijakan pembangunan pertanian. Kebijakan pembangunan pertanian tersebut diarahkan agar pertanian menjadi sektor yang tangguh, dalam jangka pendek, mampu menghadapi krisis ekonomi, dan dalam jangka panjang mampu menghadapi globalisasi dengan sistem pertanian yang berkelanjutan, dalam 
sistem ekonomi yang demokratis dan dalam pemerintahan yang terdesentralisasi (Sumodiningrat, 2001).

Agribisnis bersama-sama agroindustri merupakan pendekatan yang ditempuh untuk pengembangan pertanian industri pada masa yang akan datang karena industri pengolahan hasil pertanian (agroindustri) yang tangani secara utuh, mulai dari proses produksi, mengolah hasil, pemasaran, dan aktivasi lain yang berkaitan dengan kegiatan pertanian (agribisnis) bukan saja mampu sebagai sumber pertumbuhan baru bagi sektor pertanian (Soekartawi, 2005).

Industri tempe di Kota Manado banyak tersebar dibeberapa tempat, salah satunya Tempe Sucipto, dimana status pemiliknya yaitu usaha milik sendiri sehingga dapat dikategorikan pada industri kecil. Jenis-jenis tempe disupermarket yang ada di Kota Manado yaitu Tempe Sucipto, Tempe Gurih Murni, Tempe Daun Malang, Tempe Daun Rahma, Tempe Kawanua dan Tempe Blitar.

Tempe Sucipto merupakan salah satu produk yang sudah berkembang cukup lama, sejak tahun 1988. Industri Tempe Sucipto ini berada di Kelurahan Kleak Kecamatan Malalayang, Tempe ini juga sudah banyak di pasarkan di supermarket-supermarket yang ada di Kota Manado. Pemiliknya juga terlibat langsung yaitu mengawasi proses produksi dan sebagai penanggung jawab terhadap semua keputusan dalam setiap kegiatan produksi.

Pemasaran merupakan salah satu aspek penting dalam kegiatan bisnis yang dirancang untuk menentukan rancangan produk, harga, promosi, distribusi produk, sumber daya, dan konsep penjualan. Pemasaran mempunyai peranan yang sangat penting karena pemasaran mempunyai kedudukan sebagai perantara antara produsen dan konsumen dalam melakukan transaksi penjualan dan bertujuan untuk memuaskan kebutuhan dan keinginan konsumen. Banyak usaha kecil bermunculan dengan menyediakan produk yang kreatif, inovatif, dan menarik serta mampu memenuhi kebutuhan dan keinginan konsumen. Dengan demikian perusahaan dalam menjalankan usahanya perlu mengembangkan strategi pemasarannya, agar mampu bertahan dalam persaingan usaha yang beraneka ragam, yang berdampak pada persaingan usaha yang sejenis.

Tempe Sucipto ini sudah berdiri sejak lama dari tahun 1988 dan eksis sampai sekarang. Pabrik industri Tempe Sucipto yang dikelola sendiri oleh sebuah keluarga. Tempe Sucipto mampu mengembangkan usaha hingga saat ini ditengah-tengah persaingan usaha yang bergerak dibidang yang sama. Kualitas produk mampu di pertahankan oleh pemilik Tempe Sucipto, salah satu jenis strategi pemasaran adalah strategi bauran pemasaran 4P yang terdiri dari produk, harga, lokasi, dan promosi. Strategi bauran pemasaran digunakan untuk menghasilkan respon yang di inginkan dalam pasar sasaran.

\section{Rumusan Masalah}

Berdasarkan uraian latar belakang diatas, maka rumusan masalah dalam penelitian ini yaitu bagaimana strategi yang sudah diterapkan oleh Tempe Sucipto di Kota Manado.

\section{Tujuan Penelitian}

Mengidentifikas Strategi Pemasaran yang sudah dilakukan oleh Tempe Sucipto di Kota Manado.

\section{Manfaat Penelitian}

Penelitian ini bermanfaat sebagai bahan pertimbangan bagaimana usaha ini dalam mengambil keputusan khususnya mengenai strategi pemasaran dimasa yang akan datang.

\section{METODE PENELITIAN}

\section{Waktu dan Tempat Penelitian}

Penelitian ini dilaksanakan pada CV Cipta Panca Persada yang berlokasi di kelurahan Kleak Kecamatan Malalayang di Kota Manado Sulawesi Utara. Penelitian ini berlangsung selama 3 bulan yaitu dari bulan November sampai bulan Januari 2018, mulai dari pengumpulan data sampai penyusunan laporan hasil penelitian. 


\section{Metode Pengumpulan Data}

Jenis dan sumber data yang digunakan dalam penelitian ini adalah Data Primer dan data Sekunder. Data primer adalah data yang diperoleh dari hasil wawancara langsung kepada responden pelanggan tetap Tempe Sucipto secara sengaja yaitu: MultiMart, Jumbo, Golden, Fiesta Ria, TransMart Carrefour, Indomaret Plus. Dari keenam supermarket tersebut mewawancarai responden oleh bagian pemasaran supermarket. Kemudian yang menjadi responden pelanggan tetap yaitu: Notaris Malalayang, Dokter umum, dan Karyawan umum. Data sekunder yaitu data yang diperoleh dari literature-literatur yang berhubungan dengan judul.

\section{Konsep Pengukuran Variabel}

\section{Karakteristik Responden}
a. Jenis Kelamin (Laki-Laki/Perempuan)
b. Umur
c. Pekerjaan

1. Produk adalah pernyataan nilai konsumen terhadap produk yang ditawarkan, yang diukur melalui:
a) Kemasan Produk
b) Fitur Produk
c) Kualitas Produk
d) Daya Tahan Produk

2. Harga adalah jumlah uang yang dibayar konsumen untuk produk tertentu yang nilainya sebanding dengan nilai produk yang ditawarkan, yang diukur melalui:
a) Harga Terjangkau
b) Kesesuaian Harga dengan Kualitas
c) Daya Saing Harga

3. Promosi adalah seluruh aktifitas yang diaksanakan CV. Cipta Panca Persada untuk mempromosikan produknya kepada pasar sasaran, yang diukur melalui:
a) Penjualan Selling).

4. Tempat adalah tempat penjualan agar produk dapat dijangkau dan tersedia bagi konsumen, yang diukur melalui:
a) Lokasi Mudah di Jangkau.
b) Kenyamanan Tempat

\section{Metode Analisis Data}

Data yang diperoleh mengunakan analisis data deskriptif dan disajikan dalam bentuk Tabel. untuk menghitung Metode yang diterapkan dalam penelitian ini adalah menggunakan pengukuran skala likert. Dengan menggunakan skala likert, maka variabel yang diukur dijabarkan menjadi dimensi, dimensi dijabarkan menjadi sub variabel kemudian sub variabel dijabarkan menjadi indikator-indikator yang dapat diukur. Data yang telah terkumpul kemudian dilakukan skala pengukuran dan pemberian skor, yaitu 1 sampai 5.

Instrument pertanyaan untuk mengukur strategi pemasaran dari segi produk, harga, lokasi, dan promosi. Disusun sebanyak 10 pertanyaan dengan responden sebanyak 12 orang. Adapun penggunaan skala yaitu 1-5 untuk setiap jawaban responden selanjutnya dibagikan dalam lima kategori yakni:

1) Sangat Puas (SP) diberi skor 5

2) Puas (P) diberi skor 4

3) Cukup puas (CP) diberi skor 3

4) Tidak Puas (TP) diberi skor 2

5) Sangat Tidak Puas (STP) diberi skor 1

Dengan cara perhitungan skor masingmasing pertanyaan (Riduwan, 2011): Jumlah Skor Tiap Kriterium = Capaian Skor $\mathrm{X}$ Jumlah Responden

Jadi:

$\mathrm{S} 5=5 \times 12=60$

$\mathrm{S} 4=4 \times 12=48$

$\mathrm{S} 3=3 \times 12=36$

$\mathrm{S} 2=2 \times 12=24$

$\mathrm{S} 1=1 \times 12=12$

Jumlah skor ideal untuk setiap item pertanyaan (skor tertinggi) $=60$ (sangat puas), jumlah skor terendah $=12$ (sangat tidak puas). Dengan interpretasi nilai:

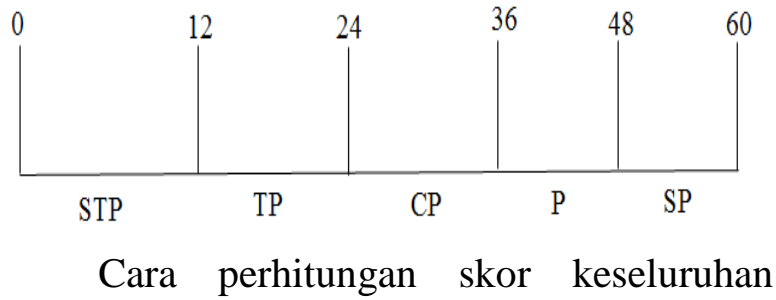
untuk mengetahui strategi pemasaran Tempe Sucipto dari segi produk, harga, lokasi dan 
promosi: Jumlah Skor Seluruh Kriterium = Capaian Jumlah Skor X Jumlah Responden X Jumlah instrument pertanyaan

$\mathrm{S} 5=5 \times 12 \times 10=600$

$\mathrm{S} 4=4 \times 12 \times 10=480$

$\mathrm{S} 3=3 \times 12 \times 10=360$

$\mathrm{S} 2=2 \times 12 \times 10=240$

$\mathrm{S} 1=1 \times 12 \times 10=120$

Jumlah skor ideal untuk keseluruhan pertanyaan $=600$ (Sangat puas), jumlah skor terendah $=120$ (Sangat tidak puas). Berdasarkan data yang dihimpun dari 10 pertanyaan yang diajukan kepada 12 responden.

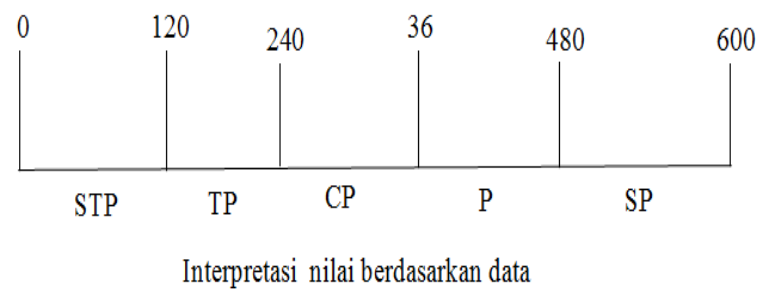

Jumlah Skor Hasil Pengumpulan

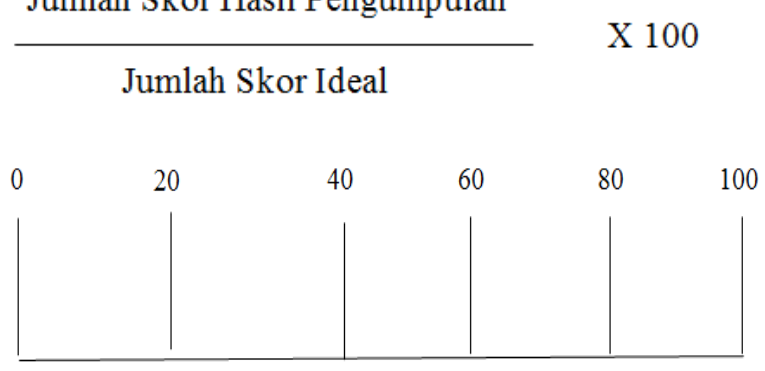

Persentase Strategi Pemasaran

Keterangan : Kriteria interpretasi skor Angka 0\% - 20\% = Sangat tidak puas Angka $21 \%-40 \%=$ Tidak puas

Angka $41 \%-60 \%=$ Cukup puas

Angka $61 \%-80 \%=$ Puas

Angka $81 \%-100 \%=$ Sangat puas

\section{HASIL DAN PEMBAHASAN}

\section{Deskripsi Tempat Penelitian}

Penelitian ini dilakukan di Jl. Santo Joseph 5 No. 15A Kelurahan Kleak Lingkungan IV Kecamatan Malalayang, nama dari industri ini CV Cipta Panca Persada. Pemilik dari industri ini bernama Ibu Sunarmi, kemudian CV Cipta Panca Persada mengembangkan usahanya dari tahun 1998. Tempe Sucipto tersebut berbahan baku kedelai, ragi tempe, dan air. Jenis-jenis Tempe Sucipto ada yang berukuran kecil dan sedang, yang berukuran kecil Rp.4.500 dan berukuran sedang Rp.7.500. Kemudian ibu Sunarmi memperluas wilayah pemasarannya, di supermarket-supermarket yang ada di kota seperti Golden, Multimart, Jumbo, HypperMart, FreshMart, Fiesta Ria, TransMart Carrefour, Indogrosir, dan Indomaret plus.

\section{Strategi Pemasaran Tempe Sucipto}

\section{a. Produk}

Kualitas Tempe Sucipto memiliki standar kualitas yang baik. Dalam proses produksi Tempe Sucipto tidak menggunakan bahan pengawet. Kemudian tekstur kacang kedelai Tempe Sucipto tetap utuh dan tidak hancur dalam hal ini yang menyebabkan tempe tetap enak dan gurih. Selain itu, kemasan produk Tempe Sucipto yang digunakan bersih dan rapi.

b. Harga

Harga pada produk Tempe Sucipto terbilang terjangkau. Hal ini, karena, walaupun harga bahan baku Tempe Sucipto yaitu kacang kedelai naik tetapi harga produk Tempe Sucipto tidak berubah atau tetap.

c. Promosi

Sampai saat ini, Tempe Sucipto belum pernah melakukan promosi baik dalam bentuk media cetak ataupun media sosial. Akan tetapi Tempe Sucipto melakukan promosi melalui perorangan atau dari mulut ke mulut (personal selling).

d. Lokasi

Lokasi usaha Tempe Sucipto berada di Jl. Santo Joseph 5 Kelurahan Kleak, yang sampai saat ini tidak pernah berpindah lokasi usaha dari tahun 1988. Selain itu lokasi usaha Tempe Sucipto bersih dan dikontrol oleh dinas kesehatan Kota Manado.

\section{Karakteristik Responden}

Responden yang digunakan dalam penelitian ini adalah responden yang sedang mengkonsumsi dan memesan langsung 
Tempe sucipto. Karakteristik umum responden dijelaskan oleh nama, usia, jenis kelamin, dan pekerjaan. Variabel tersebut ditabulasi dari jumlah keseluruhan responden.

\section{Usia}

Tabel 1 menunjukkan hasil pengamatan terhadap usia responden pada pelanggan Tempe Sucipto. Tingkatan usia menunjukkan pengaruh yang besar terhadap penilaian responden dalam memilih suatu produk.

Tabel 1. Responden Berdasarkan Usia

\begin{tabular}{ccc}
\hline Usia (Tahun) & Jumlah (Orang) & Persentase (\%) \\
\hline $30-41$ & 5 & 31,67 \\
$17-29$ & 7 & 58,33 \\
\hline Total & 12 & 90 \\
\hline
\end{tabular}

Hasil penelitian ini berdasarkan sebaran usia responden yang sedang mengkonsumsi dan menjadi pelanggan Tempe Sucipto. Kisaran usia yang paling tinggi persentasenya adalah usia 17-29 tahun yaitu 58,33\%. Pada usia 30-41 merupakan persentase yang rendah yaitu sekitar $31,67 \%$.

\section{Jenis Kelamin}

Tabel 2, menunjukkan hasil pengamatan terhadap jenis kelamin pada responden Tempe Sucipto.

\section{Tabel 2. Responden Berdasarkan Jenis Kelamin}

\begin{tabular}{ccc}
\hline Jenis Kelamin & Jumlah (Orang) & Persentase (\%) \\
\hline Laki-laki & 8 & 66,67 \\
Perempuan & 4 & 33,33 \\
\hline Total & 12 & 100 \\
\hline
\end{tabular}

Hasil penelitian ini dapat disimpulkan jenis responden yang paling dominan adalah laki-laki berjumlah 8 orang dengan persentase sebesar 66,67\%. Persentase laki-laki tidak jauh berbeda dengan persentase perempuan berjumlah 4 orang dengan 33,33\% yang melakukan transaksi di Tempe Sucipto.

\section{Pekerjaan}

Pekerjaan menjadi sesuatu hal yang wajib dipertimbangkan karena berpengaruh terhadap pendapatan. Hal ini menunjukkan bahwa pekerjaan dapat mempengaruhi seseorang dalam pengambilan keputusan.

Tabel 3. Responden Berdasarkan Jenis Kelamin

\begin{tabular}{lcc}
\hline \multicolumn{1}{c}{ Jenis Kelamin } & Jumlah (Orang) & Persentase $(\%)$ \\
\hline Karyawan & 3 & 25,00 \\
Pegawai Swasta & 3 & 25,00 \\
Dokter umum & 2 & 16,67 \\
Wiraswasta & 4 & 33,33 \\
\hline \multicolumn{1}{c}{ Total } & 12 & 100 \\
\hline
\end{tabular}

Hasil penelitian ini dapat disimpulkan sebagian besar responden Tempe Sucipto bekerja sebagai wiraswasta sebesar 4 orang dengan persentase 33,33\%. Dan karyawan, pegawai, dan dokter umum yang mempunyai persentase yang rendah yaitu sebesar $25 \%$, 16,67\%. Hal ini menunjukkan bahwa responden yang berprofesi sebagai wiraswasta memiliki tingkat pendapatan yang tidak jauh berbeda tinggi dengan karyawan, pegawai, dokte, yang mempunyai tingkat sosialisasi yang tinggi sehingga faktor kemudahan untuk mengkonsumsi dan memesan Tempe Sucipto menjadi hal yang penting dipertimbangkan.

\section{Penilaian Responden Terhadap Usaha Tempe Sucipto di Kota Manado}

\section{Produk (Product)}

Menurut responden tentang produk Tempe Sucipto memiliki kualitas yang baik dilihat dari daya tahan produk, kualitas produk yang diberikan akan mempengaruhi kepuasan dan kepercayaan konsumen terhadap produk yang ditawarkan. Dalam proses produksi, Tempe Sucipto juga tidak menggunakan bahan pengawet, hanya saja menggunakan ragi tempe hal ini menyebabkan ketahanan produk Tempe Sucipto bisa bertahan dalam jangka waktu 10 hari penyimpanan.

Kemudian rasa tempe ini tetap masih enak dan gurih. Kemudian kemasan merupakan wadah atau alat untuk menyimpan produk dengan baik agar terhindar dari kerusakan serta menjadi daya tarik konsumen dalam memilih produk. Kemasan Tempe Sucipto memakai pengemasan daun pisang dan dibungkus plastik sehingga dari konsumen menyukai dari produk ini. 
..(Nurfadila, Juliana Mandei, Lorraine Sondak)

\section{Kualitas}

Kualitas produk dapat menentukan kepuasan pelanggan yang berhubungan dengan harapan dari pelanggan itu sendiri terhadap kualitas produk yang dirasakanya. Untuk menjaga kualitas produk, Tempe Sucipto memiliki standar resep untuk setiap jenis produk. Standar resep produk selalu dikontrol oleh dinas penindustrian dan perdagangan dalam setiap kegiatan produksi. Dapat dilihat pada tabel penilian responden berikut:

Tabel 4. Penilaian dari Responden terhadap Kualitas Tempe Sucipto

\begin{tabular}{lcccc}
\hline \multicolumn{1}{c}{ Jawaban } & Skor & $\begin{array}{c}\text { Jumlah } \\
\text { Responden }\end{array}$ & $\begin{array}{c}\text { Persentase } \\
(\%)\end{array}$ & $\begin{array}{c}\text { Total } \\
\text { Skor }\end{array}$ \\
\hline Sangat Puas & 5 & 12 & 100 & 60 \\
Puas & 4 & 0 & 0 & 0 \\
Cukup Puas & 3 & 0 & 0 & 0 \\
Tidak Puas & 2 & 0 & 0 & 0 \\
Sangat Tidak Puas & 1 & 0 & 0 & 0 \\
\hline Total & & 12 & 100 & 60 \\
\hline
\end{tabular}

Hasil penelitian pada Tabel 4 mengenai penilaian responden terhadap kualitas Tempe Sucipto. Dimana $100 \%$ responden merasa sangat puas dengan kualitas yang disajikan. Dengan total skor 60. Dari hasil wawancara mengatakan bahwa responden Tempe Sucipto merasa sangat puas terhadap kualitas Tempe Sucipto. Saat ini dimana memiliki standard produk yang kurang lebih sama. Tetapi, setiap usaha tempe mempunyai keunggulannya masing-masing.

\section{Kemasan}

Kemasan merupakan wadah atau alat untuk menyimpan produk dengan baik agar terhindar dari kerusakan serta menjadi daya tarik konsumen dalam memilih produk. Tempe Sucipto memiliki kemasan yang sesuai dengan ukuran dan jenis produk. Untuk kemasan dasar, ukuran disesuaikan dengan bentuk dan ukuran Tempe, dan kemasan tambahan seperti memakai daun pisang disesuaikan dengan jumlah produk yang akan dipesan oleh responden. Dapat dilihat pada tabel penilian responden berikut:
Tabel 5. Penilaian dari Responden terhadap Kemasan

\begin{tabular}{lcccc} 
Tabel 5. Penilaian & $\begin{array}{c}\text { dari } \\
\text { Tempe Sucipto }\end{array}$ & Responden & terhadap & Kemasan \\
\hline \multicolumn{1}{c}{ Jawaban } & Skor & $\begin{array}{r}\text { Jumlah } \\
\text { Responden }\end{array}$ & $\begin{array}{c}\text { Persentase } \\
(\%)\end{array}$ & $\begin{array}{c}\text { Total } \\
\text { Skor }\end{array}$ \\
\hline Sangat Puas & 5 & 8 & 66,6 & 40 \\
Puas & 4 & 4 & 33,3 & 16 \\
Cukup Puas & 3 & 0 & 0 & 0 \\
Tidak Puas & 2 & 0 & 0 & 0 \\
Sangat Tidak Puas & 1 & 0 & 0 & 0 \\
\hline Total & & -12 & 100 & 56
\end{tabular}

Hasil penelitian pada Tabel 5 mengenai penilaian responden terhadap kemasan Tempe Sucipto. Dimana 66,6\% responden merasa sangat puas dengan kemasan yang diberikan, dan 33,3\% responden merasa puas. Dengan total skor 56. Dari hasil wawancara mengatakan bahwa responden Tempe Sucipto merasa sangat puas dari angka persentase tertinggi terhadap kemasan Tempe Sucipto. Hal ini menujukkan bahwa kemasan yang diberikan mampu memuaskan konsumen.

\section{Fitur Produk}

Fitur produk adalah sebagai alat bersaing, dimana alat bersaing ini adalah untuk membedakan produk perusahaan dengan produk pesaing. Produsen mengenalkan fitur baru yang dibutuhkan dan dianggap bernilai menjadi salah satu cara yang efektif untul bersaing. Dapat dilihat pada tabel penilaian responden berikut:

Tabel 6. Penilaian dari Responden terhadap Fitur Produk

\begin{tabular}{lcccc}
\multicolumn{5}{c}{ Tempe Sucipto } \\
\multicolumn{1}{c}{ Jawaban } & Skor & $\begin{array}{r}\text { Jumlah } \\
\text { Responden }\end{array}$ & $\begin{array}{c}\text { Persentase } \\
(\%)\end{array}$ & $\begin{array}{c}\text { Total } \\
\text { Skor }\end{array}$ \\
\hline Sangat Puas & 5 & 12 & 100 & 60 \\
Puas & 4 & 0 & 0 & 0 \\
Cukup Puas & 3 & 0 & 0 & 0 \\
Tidak Puas & 2 & 0 & 0 & 0 \\
Sangat Tidak Puas & 1 & 0 & 0 & 0 \\
\hline Total & & 12 & 100 & 60
\end{tabular}

Hasil penelitian pada Tabel 6 mengenai penilaian responden terhadap fitur produk Tempe Sucipto. Dimana 100\% responden merasa sangat puas dengan fitur produk yang dipertahankan. Dengan total skor 60. Dari hasil wawancara mengatakan bahwa 
responden Tempe Sucipto merasa sangat puas terhadap fitur produk Tempe Sucipto. Hal ini menunjukkan fitur produk ini bisa membuat responden Tempe Sucipto memilih merasa sangat puas.

\section{Daya Tahan Produk}

Daya tahan produk merupakan produk dalam penyimpanan berhari-hari, kemudian produk tersebut masih layak dikonsumsi. Dalam proses produksi, Tempe Sucipto tidak menggunakan bahan pengawet hanya saja menggunakan ragi tempe, hal tersebut tempe ini bertahan sampai 10 hari. Dapat dilihat pada tabel penilian responden berikut:

\begin{tabular}{lcccc} 
Tabel 7. Penilaian dari Responden Terhadap Daya Tahan \\
\multicolumn{4}{c}{ Produk Tempe Sucipto } \\
\hline \multicolumn{1}{c}{ Jawaban } & Skor & $\begin{array}{c}\text { Jumlah } \\
\text { Responden }\end{array}$ & $\begin{array}{c}\text { Persentase } \\
(\%)\end{array}$ & $\begin{array}{c}\text { Total } \\
\text { Skor }\end{array}$ \\
\hline Sangat Puas & 5 & 12 & 100 & 60 \\
Puas & 4 & 0 & 0 & 0 \\
Cukup Puas & 3 & 0 & 0 & 0 \\
Tidak Puas & 2 & 0 & 0 & 0 \\
Sangat Tidak Puas & 1 & 0 & 0 & 0 \\
\hline Total & & 12 & 100 & 60
\end{tabular}

Hasil penelitian pada Tabel 7 mengenai penilaian responden terhadap daya tahan produk Tempe Sucipto. Dimana 100\% responden merasa sangat puas dengan Tempe Sucipto yang disajikan. Dengan total skor 60. Dari hasil wawancara mengatakan bahwa responden Tempe Sucipto merasa sangat puas terhadap daya tahan produk Tempe Sucipto. Hal ini menunjukkan daya tahan produk ini tidak sama dengan produk tempe lainnya, Tempe Sucipto ini memiliki daya tahan sampai 10 hari sehingga responden sangat puas.

Tabel 8. Rekapitulasi dari Total Skor Strategi Pemasaran Tempe Sucipto Terhadap Produk

\begin{tabular}{llccc}
\hline No & \multicolumn{1}{c}{ Pernyataan } & $\begin{array}{c}\text { Total } \\
\text { Skor }\end{array}$ & $\begin{array}{c}\text { Tingkat } \\
\text { Penilaian }(\%)\end{array}$ & Kategori \\
\hline 1. & Kualitas & 60 & 100 & Sangat Puas \\
2. & Kemasan & 56 & 93,33 & Sangat Puas \\
3. & Fitur Produk & 60 & 100 & Sangat Puas \\
4. & Daya Tahan Produk & 60 & 100 & Sangat Puas \\
\hline & Total & 236 & 98,33 & Sangat Puas \\
\hline
\end{tabular}

Tabel 8 menunjukkan bahwa dari seluruh indikator strategi pemasaran Tempe Sucipto dari segi produk terletak pada angka 98,33\%. Artinya secara keseluruhan responden sangat puas terhadap produk dari Tempe Sucipto. Dan indikator yang memperoleh strategi pemasaran yang tinggi adalah pada kemasan, kualitas, fitur produk, dan daya tahan produk. yaitu sebesar $100 \%$. Hal ini menunjukkan bahwa responden sangat menyukai kemasan, kualitas, fitur produk,dan daya tahan produk oleh Tempe Sucipto.

\section{Harga (Price)}

Menurut produsen tentang harga dari Tempe Sucipto, Tempe Sucipto menggunakan strategi penetapan harga dari harga terjangkau, kesesuaian harga dan daya saing harga. Usaha Tempe Sucipto dalam penentuan harga merupakan suatu kunci strategi akibat dari berbagai hal seperti persaingan yang semakin ketat, rendah dan tingginya pertumbuhan ekonomi dan peluang usaha bagi yang menepati pasar. Dengan segi kesesuaian harga Tempe Sucipto baik maka harga tersebut terjangkau karena tidak mahal dan tidak murah. Yang termasuk dalam kategori terjangkau yaitu ukuran kecil, untuk kisaran harganya Rp.4.500 dan ukuran sedang dengan harga Rp.7.500. Ada beberapa macam Tempe yang di jual disupermarket manado Tempe Gurih Murni Rp.5.000. Tempe Blitar Rp.3.750. Tempe Rahma Rp.3.600. dan Tempe Kawanua Rp.4.500. Walaupun harga Tempe Sucipto sama dengan Tempe-tempe yang lain tetapi Tempe Sucipto bisa mempertahankan harga produknya sesuai dengan kualitas yang ada.

\section{Harga Terjangkau}

Harga terjangkau merupakan harga yang bisa diterima oleh pembeli. Ada beberapa jenis tempe di supermarket saat ini kemudian harga jenis tempe-tempe tersebut bersaing dengan Tempe Sucipto, tetapi pembeli memilih Tempe Sucipto karena melihat dari kualitas tempe tersebut. Dapat dilihat pada tabel penilian responden berikut: 
Tabel 9. Penilaian dari Responden terhadap Harga Terjangkau Tempe Sucipto

\begin{tabular}{lcccc}
\hline \multicolumn{1}{c}{ Jawaban } & Skor & $\begin{array}{c}\text { Jumlah } \\
\text { Responden }\end{array}$ & $\begin{array}{c}\text { Persentase } \\
(\%)\end{array}$ & $\begin{array}{c}\text { Total } \\
\text { Skor }\end{array}$ \\
\hline Sangat puas & 5 & 5 & 41,7 & 25 \\
Puas & 4 & 7 & 58,3 & 28 \\
Cukup Puas & 3 & 0 & 0 & 0 \\
Tidak Puas & 2 & 0 & 0 & 0 \\
Sangat Tidak Puas & 1 & 0 & 0 & 0 \\
\hline Total & & 12 & 100 & 53 \\
\hline
\end{tabular}

Hasil penelitian ini menunjukkan strategi pemasaran pada harga yang terjangkau oleh Tempe Sucipto. Pada Tabel 9 terdapat $41,7 \%$ sangat puas terhadap harga, $58,3 \%$ puas. Dengan total 53. Dapat disimpulkan bahwa responden merasa puas terhadap harga yang terjangkau oleh Tempe Sucipto. Harga yang ditawarkan dari Tempe Sucipto termasuk tidak mahal dan tidak murah, dibandingkan dengan tempe yang lain.

\section{Daya Saing Harga}

Daya saing harga merupakan kekuatan untuk bersaing dengan harga yang lain. Seperti harga Tempe Sucipto bersaing dengan harga tempe lain, Tempe Sucipto mampu meningkatkan kualitas produk dan menggunakan strategi yang baik kemudian bertahan menghadapi harga tempe yang lain. Dapat dilihat pada tabel penilian responden berikut:

Tabel 10. Penilaian dari Responden terhadap Daya Saing

\begin{tabular}{lcccc}
\multicolumn{5}{c}{ Harga Tempe Sucipto } \\
\hline Jawaban & Skor & $\begin{array}{c}\text { Jumlah } \\
\text { Responden }\end{array}$ & $\begin{array}{c}\text { Persentase } \\
(\%)\end{array}$ & $\begin{array}{c}\text { Total } \\
\text { Skor }\end{array}$ \\
\hline Sangat Puas & 5 & 0 & 0 & 0 \\
Puas & 4 & 10 & 83,3 & 40 \\
Cukup Puas & 3 & 2 & 16,7 & 6 \\
Tidak Puas & 2 & 0 & 0 & 0 \\
Sangat Tidak Puas & 1 & 0 & 0 & 0 \\
\hline Total & & 12 & 100 & 46 \\
\hline
\end{tabular}

Hasil penelitian data pada Tabel 10 menunjukkan strategi pemasaran pada daya saing harga yang ditawarkan oleh Tempe Sucipto. Terdapat $83,3 \%$ responden merasa puas dengan daya saing tersebut, dan $16,7 \%$ responden merasa cukup puas. Dan total skor yang diperoleh yaitu 46. Dapat disimpulkan bahwa responden Tempe Sucipto di Kota Manado merasa puas terhadap daya saing harga. Hal ini menunjukkan bahwa harga jual dari Tempe Sucipto cukup sebanding dengan kualitas yang ditawarkan.

\section{Kesesuaian Harga Dengan Kualitas}

Kesesuaian harga merupakan harga yang sesuai dengan kualitas produk, dan sesuai dengan minat pembeli. Karena walaupun harga Tempe Sucipto ini mahal tetapi pembeli sangat menyukai kualitasnya. Dapat dilihat pada tabel penilaian responden berikut:

\begin{tabular}{lcccc} 
Tabel 11. & $\begin{array}{c}\text { Penilaian dari Responden terhadap Kesesuaian } \\
\text { Harga Tempe Sucipto }\end{array}$ \\
\hline \multicolumn{1}{c}{ Jawaban } & Skor & Jumlah & Persentase & Total \\
& & Responden & $(\%)$ & Skor \\
\hline Sangat Puas & 5 & 12 & 100 & 60 \\
Puas & 4 & 0 & 0 & 0 \\
Cukup Puas & 3 & 0 & 0 & 0 \\
Tidak Puas & 2 & 0 & 0 & 0 \\
Sangat Tidak Puas & 1 & 0 & 0 & 0 \\
\hline Total & & 12 & 100 & 60 \\
\hline
\end{tabular}

Hasil penelitian data pada Tabel 11 menunjukkan strategi pemasaran pada daya saing harga yang ditawarkan oleh Tempe Sucipto. Terdapat $100 \%$ responden merasa sangat puas dengan kesesuain harga tersebut. Dan total skor yang diperoleh yaitu 60. Dapat disimpulkan bahwa responden Tempe Sucipto di Kota Manado merasa sangat puas terhadap kesesuain harga. Hal ini menunjukkan bahwa daya saing harga Tempe Sucipto membuat responden memilih sangat puas.

Tabel 12. Rekapitulasi dari Total Skor Strategi Pemasaran Tempe Sucipto terhadap Harga

\begin{tabular}{llccc}
\hline No. & Pernyataan & $\begin{array}{c}\text { Total } \\
\text { Skor }\end{array}$ & $\begin{array}{c}\text { Tingkat } \\
\text { Penilaian }(\%)\end{array}$ & Kategori \\
\hline 1. & Harga Terjangkau & 53 & 88,33 & Sangat Puas \\
2. & Daya Saing Harga & 46 & 76,67 & Puas \\
3 & Kesesuaian Harga & 60 & 100 & Sangat Puas \\
& Dengan Kualitas & & & \\
\hline & Total & 159 & 88,33 & Puas \\
\hline
\end{tabular}


Tabel 12 menunjukkan dari seluruh indikator strategi pemasaran Tempe Sucipto dari segi harga terletak pada angka 76,67\%. Artinya secara keseluruhan responden merasa cukup puas terhadap harga yang ditawarkan dari Tempe Sucipto. Dan indikator yang memperoleh penilaian strategi pemasaran yang tinggi adalah pada kesesuaian harga yaitu sebesar $100 \%$.

\section{Tempat (Place)}

Strategi bauran pemasaran pada aspek place mencakup lokasi usaha dan pendistribusian produk kepada konsumen. Bagi konsumen lokasi usaha yang baik adalah lokasi yang letaknya strategis dan efisien. Hal ini perlu diperhatikan karena lokasi usaha yang strategis memudahkan jangkauan konsumen yang akan membeli produk.

Strategi bauran pemasaran (marketing mix) aspek place yang sudah diterapkan CV Cipta Panca Persada dengan sangat baik dan berdasarkan tanggapan konsumen aspek place sudah diterapkan CV Cipta Panca Persada dengan baik, terlihat bahwa belum adanya keselarasan antara CV Cipta Panca Persada dan konsumen Tempe Sucipto.

Menurut produsen tentang lokasi/tempat dilihat dari lokasi strategis, mudah dijangkau, dan kenyamanan tempat parkir. Lokasi Tempe Sucipto berada di Kelurahan Kleak Kecamatan Malalayang. Lokasi dari Tempe Sucipto ini beberapa orang tidak mengetahui pabrik industri ini, karena pabrik ini berada didalam rumah. Mereka mengantar tempe-tempe tersebut disupermarket-supermarket yang ada di Kota Manado seperti MultiMart, Jumbo, Golden, FreshMart, Transmart Carrefour, HypperMart, Fiesta Ria dan Indogrosir. Strategi lokasi Tempe Sucipto memaksimalkan benefit perusahaan bagi industri pabrik untuk meminimumkan biaya, lokasi yang tepat mendekatkan lokasi gudang penyimpanan bahan, mudah dijangkau konsumen memungkinkan terjadi penjualan dalam jumlah banyak. Penentuan lokasi menurut produsen akan dilakukan dengan matang terdiri dari lokasi pabrik, dalam kaitanya dengan studi kelayakan bisnis. Hal yang paling rumit menurut produsen lokasi pabrik karena dari itu produsen akan pindah ke tempat yang lebih luas. Akan di pertimbangkan dalam menentukan daerah bisnis, luas daerah perdagangan, dapat dicapai dengan mudah dan lokasi saingan.

\section{Kenyamanan Tempat}

Pengelola Tempe Sucipto harus mampu menyediakan tempat yang nyaman. Kenyamanan yang dimaksud adalah tidak merasa terganggu terhadap ruangan yang sempit, kebisingan atau lainnya. Kenyamanan tempat merupakan tempat yang layak digunakan seperti kebersihan ruangan dan luas pembuatan produksi. Pabrik Tempe Sucipto juga selalu dikontrol oleh dinas kesehatan. Kemudian penataan Tempe tersusun rapi, Tempe berukuran kecil dan sedang masing-masing disusun rapi. Dapat dilihat pada tabel penilaian responden berikut:

\begin{tabular}{lcccc} 
Tabel 13. & $\begin{array}{c}\text { Penilaian } \\
\text { Kenyamanan Tempat Tempe Sucipto }\end{array}$ & \multicolumn{2}{c}{$\begin{array}{c}\text { Responden } \\
\text { terhadap }\end{array}$} \\
\hline \multicolumn{1}{c}{ Jawaban } & Skor & Jumlah & Persentase & Total \\
& & Responden & $(\%)$ & Skor \\
\hline Sangat Puas & 5 & 0 & 0 & 0 \\
Puas & 4 & 12 & 100 & 48 \\
Cukup Puas & 3 & 0 & 0 & 0 \\
Tidak Puas & 2 & 0 & 0 & 0 \\
Sangat Tidak Puas & 1 & 0 & 0 & 0 \\
\hline Total & & 12 & 100 & 48 \\
\hline
\end{tabular}

Hasil penelitian pada Tabel 13 menunjukkan bahwa sebagian besar responden yaitu $100 \%$ responden merasa puas dengan kebersihan ruangan yang ditawarkan oleh pihak Tempe Sucipto, Dengan Total skor yang diperoleh yaitu 48 dari 12 responden. Hal ini menunjukkan bahwa responden Tempe Sucipto merasa puas terhadap kebersihan ruangan.

\section{Tempat Mudah di Jangkau}

Lokasi Tempe Sucipto mudah untuk di jangkau dan di temui sehingga responden 
dapat menjangkau pabrik tersebut. Produsen biasanya mengantarkannya hanya sedikit, kebanyakan dari responden sendiri yang datang sendiri ke pabrik. Pemilik Tempe Sucipto memperluas jangkauan penjualan di berbagai supermarket yang ada di Kota Manado. Dapat dilihat pada tabel penilaian responden.

Tabel 14. Penilaian dari Responden terhadap

\begin{tabular}{lcccc} 
& \multicolumn{3}{c}{$\begin{array}{l}\text { Kemudahan Keterjangkauan } \\
\text { Sucipto }\end{array}$} & Tempe \\
\hline Jawaban & Skor & $\begin{array}{c}\text { Jumlah } \\
\text { Responden }\end{array}$ & $\begin{array}{c}\text { Persentase } \\
(\%)\end{array}$ & $\begin{array}{c}\text { Total } \\
\text { Skor }\end{array}$ \\
\hline Sangat Puas & 5 & 0 & 0 & 0 \\
Puas & 4 & 5 & 41,7 & 20 \\
Cukup Puas & 3 & 7 & 58,3 & 21 \\
Tidak Puas & 2 & 0 & 0 & 0 \\
Sangat Tidak Puas & 1 & 0 & 0 & 0 \\
\hline Total & & 12 & 100 & 41 \\
\hline
\end{tabular}

Hasil penelitian Tabel 14 menunjukkan bahwa sebagian besar responden yaitu $58,3 \%$ responden cukup puas dengan kemudahan menjangkau tempat, sedangkan $41,7 \%$ cukup puas. Total skor yang diperoleh yaitu 41 dari 12 responden. Hal ini menunjukkan bahwa konsumen merasa cukup puas terhadap kemudahan dalam menjangkau tempat yang dimana tempat Tempe Sucipto sendiri termasuk mudah dijangkau.

\begin{tabular}{lcccc} 
Tabel 15 & $\begin{array}{c}\text { Rekapitulasi } \\
\text { Pemasaran } \\
\text { Tempat }\end{array}$ & $\begin{array}{c}\text { dari } \\
\text { Tempe }\end{array}$ & Total Skor & Strategi \\
Sucipto & terhadap \\
\hline No & Pernyataan & Total & Tingkat & Kategori \\
& & Skor & Penilaian (\%) & \\
\hline 1. & Mudah di Jangkau & 41 & 68,33 & Puas \\
2. & Kenyamanan Tempat & 48 & 80 & Puas \\
\hline & Total & 89 & 74,165 & Puas
\end{tabular}

Tabel 15 menunjukkan dari seluruh indikator strategi pemasaran Tempe Sucipto dari segi tempat terletak pada angka 68,33\%. Artinya secara keseluruhan responden merasa puas terhadap tempat yang tersedia dari Tempe Sucipto. Dan indikator yang memperoleh indeks strategi pemasaran yang tinggi adalah pada kenyamanan tempat yaitu sebesar $80 \%$.

\section{Promosi (Promotion)}

Kegiatan-kegiatan promosi yang dilakukan oleh CV Cipta Panca Persada yaitu hanya personal selling yaitu penjualan dari mulut kemulut. Tempe Sucipto tidak melakukan promosi di sosial media ataupun dengan media cetak. Promosi Tempe Sucipto membujuk atau memperluaskan suatu produk kepada konsumen dengan tujuan agar konsumen tersebut pada akhirnya dapat melakukan pembelian.

\section{Promosi Personal Selling (penjualan perorangan) \\ Personal selling adalah komunikasi} langsung (tatap muka) antara penjual dan calon pelanggan untuk memperkenalkan suatu produk kepada calon pelanggan terhadap produk sehingga mereka kemudian akan mencoba membelinya.

Tabel 16. Penilaian dari Responden terhadap Personal Selling (penjualan perorangan) Tempe Sucipto

\begin{tabular}{lcccc}
\hline \multicolumn{1}{c}{ Jawaban } & Skor & $\begin{array}{c}\text { Jumlah } \\
\text { Responden }\end{array}$ & $\begin{array}{c}\text { Persentase } \\
(\%)\end{array}$ & $\begin{array}{c}\text { Total } \\
\text { Skor }\end{array}$ \\
\hline Sangat Puas & 5 & 0 & 0 & 0 \\
Puas & 4 & 7 & 58,3 & 28 \\
Cukup Puas & 3 & 5 & 41,7 & 15 \\
Tidak Puas & 2 & 0 & 0 & 0 \\
Sangat Tidak Puas & 1 & 0 & 0 & 0 \\
\hline Total & & 12 & 100 & 43 \\
\hline
\end{tabular}

Hasil penelitian Tabel 16 menunjukkan bahwa sebagian besar responden yaitu $58,3 \%$ responden puas dengan penjualan dari mulut ke mulut, sedangkan $41,7 \%$ cukup puas. Total skor yang diperoleh yaitu 43 dari 12 responden. Hal ini menunjukkan bahwa responden merasa puas terhadap promosi penjualan dari mulut ke mulut. Tempe Sucipto sampai sekarang masih belum melakukan promosi seperti media cetak, media sosial dan promosi lain-lain.

\section{Rekapitulasi Penilaian Responden terhadap Produk, Harga, Tempat dan Promosi}

Pada Tabel berikut menunjukkan rekapitulasi jumlah skor, tingkat penilaian dan interpretasi pada penilaian responden dari segi produk, harga, tempat, dan promosi. Yang diberikan oleh Tempe Sucipto: 


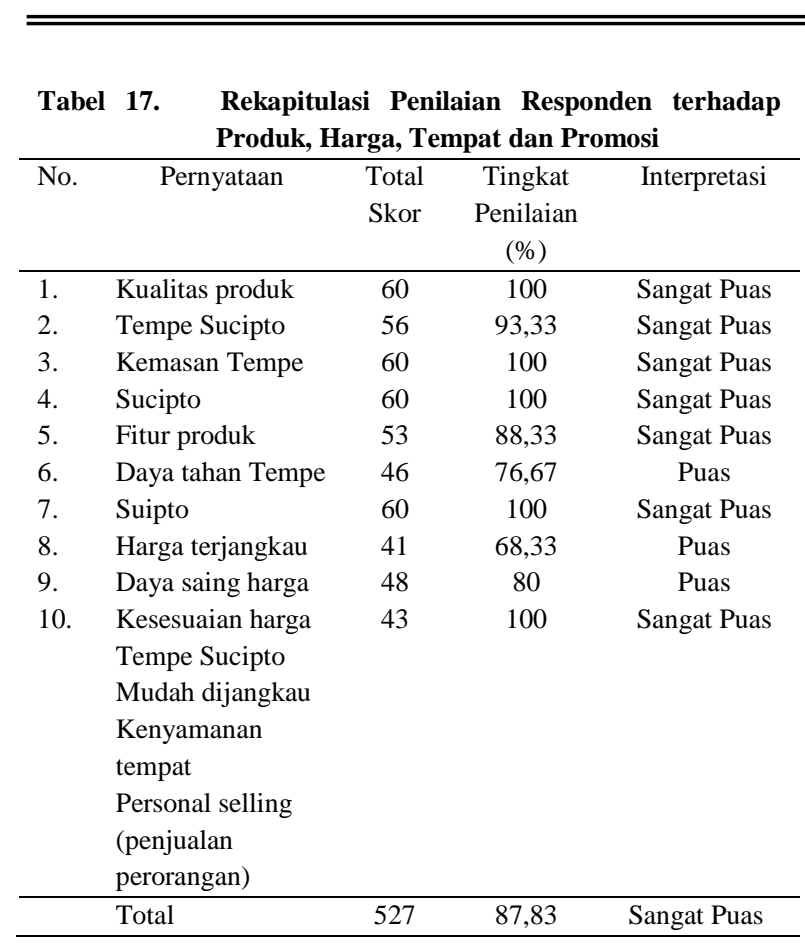

Jumlah skor ideal untuk keseluruhan pertanyaan $=600$ (Sangat puas), jumlah skor terendah $=120$ (Sangat tidak puas). Berdasarkan data yang dihimpun dari 10 pertanyaan yang diajukan kepada 12 responden, maka diperoleh total skor adalah 527 dengan tingkat penilaian responden sebagai berikut:

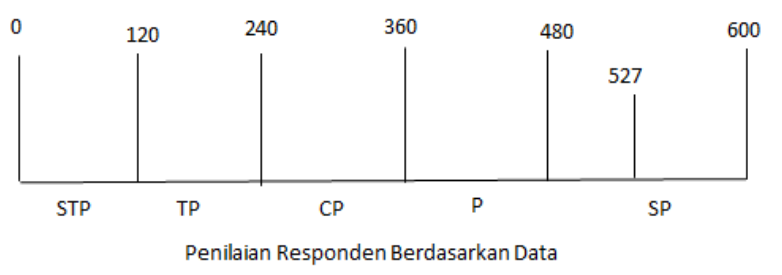

Secara persentase, angka penilaian responden terhadap produk Tempe Sucipto terletak pada:

$$
\text { Penilaian responden }=\frac{527}{600} \times 100 \%=87,83 \%
$$

Dengan penilaian responden yaitu:

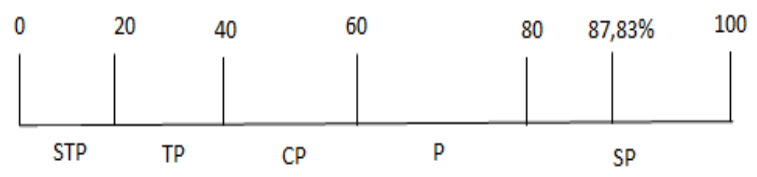

Berdasarkan hasil analisis menggunakan skala likert, maka dapat diketahui bahwa angka indeks penilaian responden Tempe Sucipto di Kota Manado dari segi produk, harga, lokasi/tempat dan promosi berada pada titik $87,83 \%$ tergolong sangat puas. Sebanyak 10 indikator pertanyaan tentang penilaian responden baik dari segi produk, harga, tempat dan promosi. Dalam penelitian ini telah menunjukkan ratarata penilaian responden berada pada tingkat sangat puas. Hal ini menunjukkan bahwa secara keseluruhan pengelola Tempe Sucipto telah mencapai tingkat penilaian yang baik meskipun masih ada beberapa indikator yang perlu diperhatikan. Tempe Sucipto tdak memiliki masalah utama dari segi produk, harga, tempat, dan promosi yang dimana responden merasa sangat puas dan puas oleh Tempe Sucipto. Berdasarkan hasil pengambilan data keseluruhan terdapat 4 variabel yang dinilai oleh responden Tempe Sucipto yaitu dari segi produk, harga, lokasi dan promosi. Dari 4 variabel tersebut produk yang memiliki tingkat kepuasan konsumen yang paling tinggi yaitu sebesar 98,33\%. Hal ini menunjukkan bahwa konsumen merasa sangat puas terhadap seluruh indikator produk oleh Tempe Sucipto.

\section{KESIMPULAN DAN SARAN}

\section{Kesimpulan}

Dari hasil penelitian ini dapat disimpulkan bahwa strategi pemasaran yang diterapkan Tempe Sucipto dari empat indikator dari segi produk tersebut yang menjadi strateginya indikator: Segi kualitas, kualitas produk Tempe Sucipto yang diberikan kepada pelanggan ataupun responden sangat baik sehingga pelanggan Tempe Sucipto tidak pernah komplen kepada produsen. Kemasan, kemasan Tempe Sucipto yang diberikan sangat menarik pelanggan ataupun responden, kemasan Tempe ini juga sangat higienis dan bersih. Daya tahan produk, daya tahan produk Tempe Sucipto 
bisa menarik pelanggan ataupun responden ingin mengkonsumsi atau memesan lagi dari daya tahan tempe ini bisa bertahan sampai 10 hari kemudian Tempe sucipto ini masih enak dikonsumsi. Kemudian fitur produk, Produsen mengenalkan fitur baru yang dibutuhkan dan dianggap bernilai menjadi salah satu cara yang efektif untuk bersaing. Dari indikator indikator tersebut jadi strategi pemasaran Tempe Sucipto yaitu terhadap produk Tempe Sucipto terbukti penilaian strategi pemasaran memiliki tingkat tertinggi.

\section{Saran}

Saran yang dapat diberikan berdasarkan hasil penelitian ini yaitu bagi pabrik Tempe Sucipto agar menambahkan promosi yang lebih efektif dan lebih memperkenalkan Tempe Sucipto. Kemudian lokasi pabrik Tempe Sucipto agar mencari tempat lokasi pabrik agar responden dan pelanggan lebih mudah menjangkaunya.

\section{DAFTAR PUSTAKA}
Soekartawi, 2005. Agribisnis Teori dan Aplikasinya.Universitas Indonesia. Jakarta.
Sumodiningrat, Gunawan. 2000.
Pembangunan Ekonomi Melalui
Pengembangan Pertanian., PT Bina
Rena Pariwisata, Jakarta.

